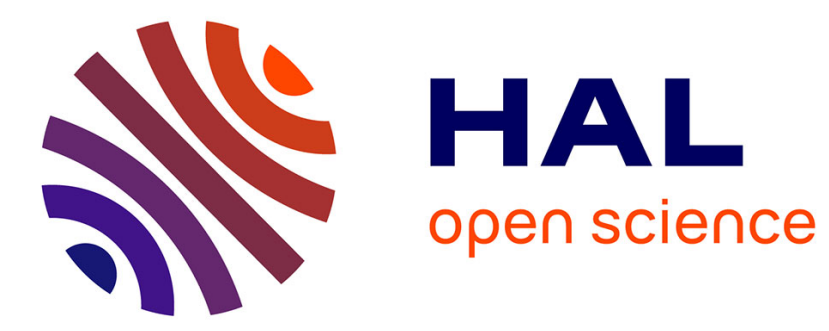

\title{
Contribution of human and biophysical factors to the spatial distribution of forest fire ignitions and large wildfires in a French Mediterranean region
}

\author{
Julien Ruffault, Florent Mouillot
}

\section{- To cite this version:}

Julien Ruffault, Florent Mouillot. Contribution of human and biophysical factors to the spatial distribution of forest fire ignitions and large wildfires in a French Mediterranean region. International Journal of Wildland Fire, 2017, 26 (6), pp.498-508. 10.1071/WF16181 . hal-01681548

\author{
HAL Id: hal-01681548 \\ https://hal.science/hal-01681548
}

Submitted on 15 May 2018

HAL is a multi-disciplinary open access archive for the deposit and dissemination of scientific research documents, whether they are published or not. The documents may come from teaching and research institutions in France or abroad, or from public or private research centers.
L'archive ouverte pluridisciplinaire HAL, est destinée au dépôt et à la diffusion de documents scientifiques de niveau recherche, publiés ou non, émanant des établissements d'enseignement et de recherche français ou étrangers, des laboratoires publics ou privés. 
1 Title: Contribution of human and biophysical factors to the spatial distribution of

2 forest fire ignitions and large wildfires in a French Mediterranean region

3 Julien Ruffault ${ }^{1,2,3,4}$ and Florent Mouillot ${ }^{1,}$

4 (1) IRD, UMR CEFE (Centre d'écologie fonctionnelle et évolutive), IRD 1919 route de $5 \quad$ Mende Montpellier cedex 5, France.

6 (2) Aix-Marseille University, CEREGE UM 34 CNRS, Aix en Provence, France.

7 (3) IRSTEA, UR RECOVER, Aix en Provence, France

8 (4) IMBE, Aix Marseille Université , CNRS, IRD, Avignon Université , Marseille

9 Cedex 03, France.

$10 *$ Corresponding author: Julien Ruffault

$11 \quad$ E-mail: julien.ruff@gmail.com

12 Tel: +33467613292

13 Fax: +33467412138

14 Running head: Spatial distribution of forest fires 


\section{Abstract}

16 Identifying the factors that drive the spatial distribution of fires is one of the most 17 challenging issues facing fire science in a changing world. We investigated the relative 18 influence of humans, land cover and weather on the regional distribution of fires in a

19 Mediterranean region using boosted regression trees and a set of seven explanatory 20 variables. The spatial pattern of fire weather, which is seldom accounted for in regional 21 models, was estimated using a semi-mechanistic approach and expressed as the length 22 of the fire weather season. We found that the drivers of the spatial distribution of fires 23 followed a fire size dependent pattern in which human activities and settlements mainly 24 determined the distribution of all fires whereas the continuity and type of fuels mainly 25 controlled the location of the largest fires. The spatial structure of fire weather was 26 estimated to be responsible for an average of $25 \%$ of the spatial patterns of fires, 27 suggesting that climate change may directly affect the spatial patterns of fire hazard in 28 the near future. These results enhance our understanding of long term controls of the 29 spatial distribution of wildfires and predictive maps of fire hazard provide useful 30 information for fire management actions.

\section{Summary}

32 We examined the human and biophysical factors driving the regional distribution of 33 wildfires in a Mediterranean area. We found a fire size dependent pattern in which 34 humans control the distribution of all fires whereas land cover and fire weather mainly 35 explained the location of the largest fires. These factors should therefore be taken into 36 consideration when projecting fire hazard. 


\section{Introduction}

Wildfire is a widespread ecological disturbance, but one with a heterogeneous spatial distribution (Krawchuck et al. 2009; Bowman et al. 2011). Identifying the drivers of the distribution of fires is crucial for the design of appropriate fire policies, especially in regions where fire regimes are being altered by global changes as is the case in the Mediterranean area (Moreira et al. 2011).

Regional fire distribution is the result of interactions between three environmental conditions: ignitions patterns, fuel availability and atmospheric conditions that favor combustion (Moritz et al. 2005; Archibald et al. 2009). Biophysical factors, including fuel type and continuity, topography and weather conditions play an important role in determining the spatial patterns of fires (Parks et al. 2012; Parisien et al. 2014). Humans also affects regional fire distribution through three main mechanisms: by igniting fires, by limiting the spread of fires and by modifying land cover (Bowman et al. 2011). Because of the complex interactions between biophysical and human influences, the extent to which they determine the spatial patterns of fires varies geographically, according to ecosystem characteristics (Parisien and Moritz 2009), orographic and synoptic conditions (Heyerdahl et al. 2001) or to the level and nature of the human imprint (Parisien et al. 2016).

In the Euro-Mediterranean region, evidence is accumulating that the spatial pattern of ignitions is mainly determined by human settlements and activities, while the continuity and type of fuels largely control fire spread probabilities, and therefore the location of the largest fires (Moreira et al. 2010; Duane et al. 2015; Fernandes et al. 2016). However, there is no consensus on the extent to which spatial variations in weather control the spatial patterns of fires at landscape to regional scales (Moreira et al. 2011). 
Yet, in regions of complex orography like the Mediterranean, we observe steep weather gradients (Lionello et al. 2006) that could help define areas where wildfires are most likely to occur (Moritz et al. 2010). In the Mediterranean, this knowledge gap is often mentioned as one of the major source of uncertainty when projecting future fire likelihood at the regional level (Piñol et al. 1998; Martínez et al. 2009; Moreira et al. 2011) and part of the problem is the difficulty in identifying and mapping wildfire danger.

First, quantifying the contribution of weather requires unravelling the multiscale temporal relationships between climate and fire activity. Climate affects fire probability both indirectly, through its long term control of vegetation, and directly through what is termed fire weather, i.e. the weather conditions that influence fire ignition, fire behavior and suppression (Bradstock 2010). In turn, fire weather is the result of atmospheric processes at different time scales: fuel production and desiccation in the medium term and instantaneous conducive atmospheric conditions in the short term (Ruffault et al. 2016). Hence, linking fire activity to mean climatic conditions helps determine the biophysical niche of fires (e.g. Parisien and Moritz 2009; Whitman et al. 2015). These indices nevertheless cannot separate the indirect from the direct effects of climate on the spatial distribution of fires, nor do they represent the co-occurrence of several multiscale weather events associated with fires.

Second, in regions with marked climate seasonality like the Mediterranean, variations in climate over time have a much greater influence than spatial variations, making it difficult to extract the impact of its spatial component on fire activity. Finally, as the fire-weather relationship is shaped by both the vegetation (Pausas and Paula 2012) and human practices (Marlon et al. 2008; Ruffault and Mouillot 2015), the weather 
conditions that drive the fire occurrence and fire spread processes can vary considerably in space and over time (Ruffault and Mouillot 2015; Higuera et al. 2015).

In this context, we conducted a comprehensive evaluation of the effects of weather, fuel and human variables on the spatial distribution of fires in a French Mediterranean area (Fig. 1). In this area, the fire regime is dominated by typical Mediterranean crown fires in shrublands and in mixed oak-pine woodlands, which are mostly ignited by humans and usually last less than a day (Fréjaville and Curt 2015). Fire activity is "droughtlimited", i.e. fires are most likely to occur when two conditions occur simultaneously: vegetation drought and meteorological fire prone days (Ruffault et al. 2016, 2017). We used a set of seven explanatory variables describing the spatial patterns of human, fuel and fire weather factors in the study area. We assessed the relative importance of environmental controls on the spatial distribution of fires for individual variables as well as for the grouped variables humans, land cover and weather. Our objectives were (i) to identify the spatial structure of fire weather, (ii) to quantify the contribution of the human, land cover and weather variables to the spatial distribution of fires, and (iii) to assess whether the relative contribution of these factors varies with increasing fire size.

\section{Materials and Methods}

\section{Study area}

The study area covers four French administrative districts (total area 21,637 $\mathrm{km}^{2}$ ) in southern France (Fig. 1). The climate is Mediterranean with hot dry summers, cool wet winters and high inter-annual variability. The rainfall gradient depends on the topography and ranges from $550 \mathrm{~mm}$ at the coast (elevation $=0 \mathrm{~m}$ ) to $1,630 \mathrm{~mm}$ in the central foothills (elevation $=1,450 \mathrm{~m}$ ). Closed forests dominated by Mediterranean evergreen tree species (Quercus ilex, Pinus halepensis) and shrublands (Cistus 
monspeliensis, Quercus coccifera) cover $65 \%$ of the study area (French national forest inventory, 2006). Agricultural land use (mainly vineyards) accounts for $28 \%$ and urban areas the remaining $7 \%$.

\section{General method and selection of the variables}

We assessed the drivers of the spatial distribution of fires for a range of final fire size classes by modeling the relationship between fire presence as the response variable and a set of potential human, weather and land cover factors as predictor variables. The spatial partitioning of the study area followed the French fire management agency's 4$\mathrm{km}^{2}$ grid system for the French territory. We limited our analysis to the most recent period (1990-2006) to avoid biases resulting from the shift in fire activity observed at the end of the 1980s in the study area (Ruffault and Mouillot 2015). For each class of final size of fire, a binary variable was generated to represent its corresponding spatial fire distribution for each grid cell, positive if at least one fire had occurred over the 17year study period. The decisions to select a variable (or not) were based on both objective analysis (ease of interpretation and a range of final fire size classes) and the results of previous studies conducted in the Euro-Mediterranean region (Martínez et al. 2009; Moreira et al. 2010; 2011; Oliveira et al. 2012; Duane et al. 2015; Fernandes et al. 2016). Seven variables (Table 1) were selected to build a model by iteratively eliminating correlated and non-informative variables from an original set of 21 variables (Table S1). To this end, the correlation between all explanatory variables was assessed to identity variables correlated above a threshold of $|\rho|=0.7$. Then the fits of spatial fire distributions were assessed against these two correlated variables to decide which variable to retain. Variables with spurious effects were also discarded. Regional maps of fire distribution, weather, human and land cover variables were then collected at the $4-\mathrm{km}^{2}$ grid scale. For land cover and human factors, all the explanatory variables 
134 were mapped to reflect the average conditions over the study period (1990-2006) as

135 closely as possible, but due to the lack of historical data for some variables, the

136 conditions prevailing on a single date had to be chosen as representative of the 17-year

137 period (see details below). However, as no major economic or societal changes

138 occurred during this period, we did not expect this simplification to be a major 139 limitation.

$140 \quad$ Fire data

141 The location, date and size of fires in the period 1990 to 2006 were extracted from the

142 PROMETHEE fire database (available on line at www.promethee.com). This database

143 is managed by the French forestry services and includes the final size, the day and

144 location of ignition for each registered fire on a $4-\mathrm{km}^{2}$ reference grid. A total of 6,381

145 fires occurred in the study area between 1990 and 2006. Most were small (median = 1

146 ha; mean $=6.5 \mathrm{ha}$ ), and because only 16 fires spread beyond the area of the reference

147 grid cell (400 ha), we assumed that fires did not spread beyond their ignition grid cell.

148 Each fire was then attributed to one or more of the five classes of final fire size burned

149 area: $>0$ ha (all fires); $>1$ ha; $>6$ ha; $>15$ ha; $>30$ ha (large fires); representing

150 respectively the $0^{\text {th }}, 50^{\text {th }}, 90^{\text {th }}, 95^{\text {th }}, 97^{\text {th }}, 98^{\text {th }}$ percentile of the fire size distribution over

151 the study period. A binary response variable was then selected to describe the presence

152 or absence of fire in each grid cell. Forty-six percent of the grid cells experienced at

153 least one fire over the 1990 to 2006 period, but this percentage decreased sharply with

154 an increase in fire size. For instance, fires covering an area of more than 6 ha and 30 ha

155 were observed in $10 \%$ and $3.3 \%$ of grid cells, respectively (Fig. 1). 
157 Spatial variations in fire weather were described by using a single and integrative

\section{Fire weather maps} variable and expressed for each grid cell as the fire weather season length (hereafter FWSL, i.e. the annual number of days suitable for burning). This approach is therefore similar to that successfully used by Jolly et al. (2015) on a global scale, but in our case, was based on the prior identification of the fire-weather relationship. In addition, as the conditions controlling the probabilities of fire start differ from those driving fire spread in Mediterranean France (Ruffault and Mouillot 2015; Ruffault et al. 2016, 2017), the FWSL was computed for each fire size class. We used the following two-step methodology to map the FWSL:

(i) First, to determine the fire-weather relationship, we assessed the relative importance of several key weather variables in the probability of fire occurrence using the spatiotemporal framework of Ruffault and Mouillot (2015). For each fire, we extracted the associated weather conditions in our basic spatio-temporal unit (or voxel, on 4-km² grid cells and at a daily time step). Boosted regression tree (BRT, see description below) models were then used to describe the relationship between fire occurrence and the weather by comparing the conditions associated with fire voxels (positive elements) with those associated with a sample of non-fire voxels (absence elements). Five variables were used to capture the weather conditions driving fire occurrence and fire spread probabilities: a proxy of fuel moisture content of litter (Surface drought), a proxy of fuel moisture content of living biomass (Vegetation drought), relative air humidity, temperature and wind speed. The two proxies of fuel moisture content were derived from a daily process based water-budget model, validated in forest stands in southern France by Ruffault et al. (2013), and computed here for a single plant functional type (PFT) representative of the deep-rooted evergreen woody species (trees and large 
181

182

183 184 stress).

185

186

shrubs) encountered in our study area. Surface drought is expressed as the relative soil water content of the uppermost soil layer. Vegetation drought is expressed as the ratio of actual evapotranspiration to maximum transpiration (transpiration without water

(ii) In the second step, we used the regional statistical models between weather variables and fire occurrence to determine the daily probabilities of fire occurrence in each grid cell between 1990 and 2006. The FWSL was then determined as the averaged annual number of days when their fire probability was higher than a given probability threshold. To facilitate comparisons among fire size classes, this threshold value was set as equal to the prevalence (percentage of positive fire voxels) observed in the original sampling dataset.

Daily historical observations of precipitation, relative humidity, temperature, and global solar radiation, used as inputs in the process based water budget model and in the BRT analyses, were obtained from the SAFRAN dataset (Vidal 2010). SAFRAN is a reanalysis of daily surface observations on an $8-\mathrm{km}$ resolution grid of France. To match the resolution of our spatial sampling unit (national reference grid, $2 \times 2 \mathrm{~km}$ ), these daily variables were previously re-interpolated using altitude-dependent methods described and validated over the region by Ruffault et al. (2014). Soil data used as inputs for simulations of the water budget were extracted from the regional DONESOL database (1/250000; INRA; Gaultier et al. 1993).

\section{Human variables}

Three variables were selected to represent the pattern of human influence over the study area: road density, housing density, and the percentage of wildland urban interface (WUI). Vectorial information related to roads and human habitats was extracted from 
the BD-Topo database (IGN 2007). The density of roads is expressed as the total road

206 length per unit land area. The density of houses was calculated as the fraction of unit 207 area covered by urban polygons. The WUI percentage was calculated as the distance to 208 aggregated and open human habitat according to the method proposed by Lampin209 Maillet et al. (2010) and is expressed as the percentage of WUI in each grid cell. Fig. 210 S1 shows a map of these variables.

\section{Land cover variables}

212 Three variables were selected to represent the patterns of land cover in the study area: 213 percentage of shrubland area, percentage of forest area, and the diversity of vegetation 214 types. All these variables were derived from the Corine land cover database 2000 (EEA 215 1994), which was previously reclassified into four main categories (shrublands, forests, 216 grasslands and other non-fire prone areas: urban area, crops, bare ground) according to 217 the method described in Moreira et al. (2010). Shrubland and forest areas were 218 calculated as the percentage area of the grid cell covered by forest and shrubland type 219 vegetation, respectively. The landscape diversity represents the diversity in the 220 fractional distribution of land cover types that make up the landscape and was 221 calculated with the Shannon diversity index with a 10-km wide moving window using 222 FRAGSTATS V3 (McGarigal et al. 2002). Fig. S1 shows a map of these variables.

\section{$223 \quad$ Fire spatial model}

224 We used a machine-learning algorithm, boosted regression trees (BRT; De'ath 2007; 225 Elith et al. 2008) to predict the spatial pattern of fires. BRT uses the iterative 226 partitioning approach of regression trees, but reduces predictive error by "boosting" 227 initial models with additional, sequential trees that model the residuals in randomized 228 subsets of the data (De'ath 2007; Elith et al. 2008). BRT methods have been 
increasingly recommended for ecological analyses because of their flexibility in modeling complex nonlinear relationships and interactions without the restrictive assumptions of parametric statistics (Olden et al. 2008).

BRT models need information about the presence and absence of fires in the grid cells to be able to determine the conditions associated with fire. To be able to compare the models more easily, the prevalence (the percentage of fire presence grid cells in the sample dataset) was fixed at 0.1 . The absence data for each fire size class was randomly selected from the pool of absence grid cells. The learning rate $(l r)$, the tree size or tree complexity $(t c)$ and the number of trees $(n t)$ are the main parameters of BRT models and were set according the procedure recommended by Elith et al. (2008). For all models, a bag fraction of 0.5 was used, meaning that, at each step, $50 \%$ of the data were randomly drawn from the training dataset. As the number of samples could subsequently vary between models, we set $t c$ to 4 (based on preliminary analyses) and then determined $l r$ as a value that resulted in the average test error being minimized between approximately 1,000 and 2,000 trees (Elith et al. 2008). The $n t$ in each BRT model was selected automatically using 10 fold cross-validation to avoid model overfitting. BRT models were computed in R with the gbm package (Ridgeway 2006) and custom functions created by Elith et al. (2008) computed using a Bernoulli (logistic) error structure.

We used the area under the receiver operating characteristics $(R O C)$ curve $(A U C)$ to evaluate the suitability of the models. For each model, $70 \%$ of the observations were randomly selected from the complete dataset to build the statistical model (training dataset). The remaining observations (30\%) were used to evaluate the accuracy of model classification (validation dataset). We also report the commission error (false 
253 positive rate) and omission error (false negative rate) at the probability threshold that 254 maximizes the sum of sensitivity (the fraction of true positives) and specificity (the 255 fraction of false positives) values (Lobo et al. 2007). To limit the stochasticity in model 256 outcomes caused by the subsampling and bagging, we created an ensemble of 25 BRT 257 models and then averaged the results.

258 We interpreted the BRT models by first looking at the relative contribution of the 259 variables to the predictive models. The contribution of the different predictors was 260 estimated from the sum of squared improvements associated with that variable and 261 averaged across all trees in the boosted model (De'ath 2007; Elith et al. 2008). The 262 relative importance of environmental factors controlling the spatial distribution of fires 263 was assessed for individual variables as well as for the grouped variables for humans, 264 land cover and weather (Table 1). The contributions of the grouped variables were 265 determined by adding the percentage contributions of their constituent variables. To 266 estimate the degree of similarity among variable contributions among different classes 267 of fire size classes, a rank (Spearman) correlation was performed on the mean 268 contribution of the variables in pair-wise combinations of fire size classes. A lack of 269 significance $(\mathrm{p}<0.05)$ in a correlation indicates that the relative importance of 270 environmental controls differs among sizes. We also examined the relationship between 271 the dependent and independent variables by plotting the partial dependencies of 272 responses to individual predictors. Finally, we computed the fire hazard maps, which 273 were derived from statistical models between the spatial distribution of fires and its 274 environmental drivers. 


\section{Results}

\section{Regional patterns of fire weather season length}

Fire activity in southern France was shown to be mainly linked to drought conditions but with an increasing contribution of wind speed with increasing fire size (Fig. S2, see also Ruffault and Mouillot 2015). A significant spatial gradient was observed in the fire weather season length (FWSL), as shown for two contrasted sizes of fires: fires $>0$ ha (hereafter all fires) and fires $>30$ ha only (hereafter large fires) (Fig. 2). For all fires, the FWSL ranged from 40 to1 80 days.year ${ }^{-1}$ (Fig. 2a). The lowest values were observed in the western part of the region where rainfall and mean temperature are respectively, higher and lower than the regional means (Ruffault et al. 2013). By contrast, a longer FWSL was observed in the drier coastal areas (Ruffault et al. 2013). Some marked local variations were also detected according to the variations in soil water holding capacity that influenced the variations in live fuel moisture content, and in turn, the FWSL. For large fires, the regional pattern of fire weather was similar to the one observed for all fires (Fig. 2b) but with a coherently shorter FWSL (ranging from about 10 days.year ${ }^{-1}$ in the western part of the region to 100 days.year $^{-1}$ in the coastal area).

Relative contribution of climate, land-cover and human variables to the spatial distribution of fires.

The BRT fire spatial models performed well (AUC $\geq 0.72$ ) and similarly in the different fire size classes (Table 2), with commission and omission errors of about $30 \%$. The performance metrics variability was higher for larger fire size classes, most likely due to the exponential reduction in the number of "presence" grid cells with increasing fire size. 
298 The relative contribution of the explanatory variables to the spatial fire distribution 299 models showed a size-dependent pattern (Fig. 3). The distribution of all fires was 300 largely controlled by the percentage of wildland urban interface (WUI; $26.0 \%)$, the 301 FWSL (18.8\%) and road density (16.4\%). The relative importance and ranking of the 302 explanatory variables changed significantly with an increase in fire size: a major shift 303 was observed between fires $>1$ ha and fires $>6$ ha (Table 3, Spearman test, p304 value $<0.1$ ). When the individual contributions of all fires and large fires were 305 compared, there was a significant increase in shrubland area (from $6 \%$ to $24 \%$ and from $30618.4 \%$ to $27 \%$, respectively) (Fig. 2c) and in the FWSL (Fig. 2a) and a significant 307 decrease (from $26 \%$ to $9 \%$ ) in WUI (Fig. 2f). When these contributions were grouped, 308 we observed marked control of human variables over spatial fire patterns, but increasing 309 influence of climate and land cover factors with increasing fire size (summarized in $310 \quad$ Fig. 3e)

311 Individual relationships between each explanatory variable and fire hazard showed 312 different patterns (Fig. 4). Fire probabilities were higher under intermediate levels of 313 human pressure (Fig. 4b,d,f) but this pattern tended to disappear with increasing fire 314 size. As one might expect, the FWSL positively and monotonically affected fire 315 probability, regardless of the final fire size (Fig. 4a). Finally, vegetation and land cover 316 variables showed some contrasting patterns. The probability of large fire occurrence 317 increased with an increase in the shrubland area (Fig. 4c) but decreased with increasing 318 forest area. The probabilities of ignition and large fires both increased with higher 319 landscape diversity but the impact of this variable was greater on fire ignitions (Fig. $320 \quad 4 \mathrm{e})$. 
321

322

323

\section{Fire hazard maps}

Despite the variability of fire hazard at local scale, some regional patterns emerged with, on average, less relative probability of fire in the western part than in the southern and eastern parts of the region (Fig. 5a). A very similar pattern was observed for larger fires, but with more contrasted differences (Fig. 5b).

\section{Discussion}

The peculiar Euro-Mediterranean context points to an advanced stage of anthropogenic fire-regime transformation (Moreira et al. 2011). Accordingly, in southern France, where the majority of fires are caused by humans (Curt et al. 2016), the distribution of fires was mainly driven by variables that reflect the level and nature of human pressure (Fig. 3). This is further evidence for the overwhelming impact of anthropogenic factors on the spatial patterns of fire ignitions in the Euro-Mediterranean area (Martinez et al. 2009; Oliveira et al. 2012), as also observed in a number of fire prone areas where anthropic pressure is high and can override the effects of biophysical factors (Cardille et al. 2001; Syphard et al. 2008; Hawbaker et al. 2013; Faivre et al. 2014; Mann et al. 2016). Fire-start hazard was higher under intermediate levels of anthropogenic pressure (Fig. 4), a pattern that has been reported in other anthropogenic fire regimes (Syphard et al. 2007; Moreira et al. 2010, Parisien et al. 2012).

In southern France, the greater influence of human-related variables on the spatial pattern of fires tended to decrease with an increase in fire size, with a concomitant increase in the importance of fuel characteristics and land cover (Fig. 3). This result strengthens the fire size dependence hypothesis that was previously proposed to explain the spatial patterns of fires in Western Europe (Moreira et al. 2010). It also suggests that fuel fragmentation is one the most important factors limiting the occurrence of 
345 large fires in the Mediterranean. A direct outcome of this phenomenon is that the areas

346 where most wildfires occur did not match those where the largest fires occur (Fig. 5).

347 Most small fires typically occurred in locations where human development and natural

348 vegetation intermingle, in the most complex landscape mosaics and with frequent or

349 long lasting droughts. By contrast, large fires are most likely to occur in landscapes

350 characterized by a dense shrubland cover, low but still significant human pressure to

351 enable frequent ignitions, and by frequent severe fire weather conditions favoring

352 extreme fire behavior and hence ineffective fire suppression operations. The greater

353 probability of large fires in shrublands compared to forested ecosystems is common in

354 the Mediterranean basin (Moreira et al. 2011) and was particularly high in

355 Mediterranean France although we were unable to conclude whether it is due to the

356 higher flammability of this type of fuel or less intense fire suppression efforts in

357 shrublands than in forested ecosystems. Finally, we did not observe a higher probability

358 of large fires in continuous and homogeneous landscapes (Fig. 4), in contrast to what

359 is generally observed (Cardille et al. 2001; Heyerdahl et al. 2001; Viedma et al. 2009;

360 Loepfe et al. 2010; Fernandes et al. 2016) or simulated from landscape fire succession

361 models (Hargrove et al. 2000; Cary et al. 2006). One possible explanation is the need

362 for a balance between a complex urban/wildland interface and homogeneous landscape

363 pattern for fires to start and spread, but generally leading to a weak effect of landscape

364 diversity on large fire hazard. In addition, our large fire threshold ( $>30$ ha) is low

365 compared to other regions and ecosystems (Hantson et al. 2015) and it is therefore also

366 possible that the relative contribution of weather, human and land-cover factors is quite

367 different when larger fires are considered (Liu et al. 2013; Fernandes et al. 2016).

368 One interesting finding of our study is that the spatial variations in weather conditions 369 also largely influenced the location of fires in Mediterranean France. We estimated that 
the FWSL accounted for between $20 \%$ and $30 \%$ in the BRT models predicting the spatial distribution of fires. These figures are not surprising given the marked regional and local variability in drought and wind conditions (Ruffault et al. 2013), two of the critical variables for the probability of large fires occurring in this region (Ruffault et al. 2017). Given the rapid and non-uniform changes towards hotter and drier conditions that are projected in the Mediterranean area in the coming decades (López-Moreno et al. 2008), the spatial patterns of fire hazard might be modified through some changes in fire weather. Of particular concern are the western and northern parts of our study area both located at the edge of the Mediterranean bioclimatic area. In these peculiar locations, the FWSL is still short (Fig. 3) but these areas are expected to undergo the most intense changes (Ruffault et al. 2014).

A similar hypothesis about the control of weather over the spatial patterns of fires could apply to several parts of the Euro-Mediterranean region. Unfortunately, it is difficult to compare our figures with the results of similar studies, as most spatial models of wildfires did not include the impact of fire weather in a meaningful way (e.g. Martínes et al. 2009; Moreira et al. 2010; Duane et al. 2015). However, the 30\% reported here for large fires is in the same order of magnitude as the $29.2 \%$ found by Parisien et al. (2011a) in a flat boreal region with a relatively low fire suppression. One might have expected the influence of fire weather to be higher in our study area because the topography generally increases the spatial variations in weather. But many other factors can also influence the importance of fire weather in controlling the spatial patterns of fires, and in many different ways. For instance, evaluating the net effect of suppression policies is challenging because they may simultaneously have opposite influences. On the one hand, fire suppression policies are likely to reduce the importance of the spatial structure of weather on wildfire probabilities. On the other hand, fire suppression also 
distorts the relationship between fires and the weather and can increase the role of specific combinations of synergic weather conditions (or fire weather types, Ruffault et al. 2016) for which fire suppression operations are not effective. For instance, it is likely that the implementation of a new fire policy in southern France resulted in an increase in the relative probability of fires in the windiest areas (Ruffault and Mouillot 2015).

Here our aim was to provide a comprehensive understanding of the regional spatial pattern of wildfires and we consequently limited our analyses to a small number of relevant explanatory variables (Table 1). Nevertheless, we obtained AUC values that are in the same range as those observed by other authors predicting the spatial distribution of fires at a regional scale in the Mediterranean (Moreira et al. 2010, Duane et al. 2015,) and elsewhere in fire prone areas with fragmented landscapes (Syphard et al. 2008; Bar-Massada et al. 2013; Hawbaker et al. 2013; Faivre et al. 2014). Three important methodological choices are worth mentioning here. First, a variable that estimated the distance to the nearest fire station (Table S1) had to be discarded from our statistical models despite its relative contribution in BRT models (up to $14 \%$ for large fires, not shown). Indeed, we observed that fire hazard was higher in areas located close to the fire stations, surely because they were intentionally located to maximize suppression, as also shown by Robinne et al. (2016) in a region in Canada. This is a good example of the complex impact of humans on the spatial patterns of fires, with both direct and indirect impacts that challenge our assessment of their net effect (Brotons et al. 2013; Parisien et al. 2016). In our study, we separated groups of human and land cover variables, which was helpful from a methodological point of view (Fig. 3, Tables 1 and 2) but this boundary is very blurred in Mediterranean landscapes that are largely shaped by the history of human activities. Our second important methodological choice was not to include topographical variables. There is compelling 
420

421

422

423

evidence that topography directly influences fire spread through slope steepness and local atmospheric air movements (Rothermel 1991) and is related to several spatial fire metrics (Parks et al. 2012; Duane et al. 2015; Liu and Wimberley 2016) but the indirect effects of topography, expressed through contrasting vegetation types, fuel amounts or fuel moisture are often more relevant (Mouillot et al. 2003). In fact, the indirect effects of topography on vegetation were partially taken into consideration in our study, through our altitude dependent methods for the interpolation of daily precipitation and temperature data, and the impact of weather on LAI estimations and functional drought indices. Third, we paid particular attention to providing some realistic estimations of the spatial structure of fire weather. To this end, we based our approach on the prior identification of the fire-weather relationship using a few relevant weather variables and drought indices, thereby avoiding generic fire danger indices whose validity may be limited in areas, ecosystems or anthropogenic contexts for which they were not designed. In addition, our drought indices were estimated with a process based water balance model and therefore have the advantage of accounting for weather, local soil conditions and vegetation functioning in a single metric. The use of such functional indices as proxies of fuel dryness is a step forward in our understanding of the fuelweather interactions (Ruffault and Mouillot 2015; Williams et al. 2015; Boer et al. 2016).

\section{Conclusion}

Wildfire is a highly scale-dependent process (Moritz et al. 2005), as are the relative contributions of the drivers of wildfire distribution (Heyerdahl et al. 2001; Parisien and Moritz 2009; Parisien et al. 2011b) but the implementation of effective fire policies and landscape management relies on the identification of the drivers of wildfire at landscape 

452 fire hazard in the Mediterranean region.

to regional scales. Here, we provide evidence that, in the French Mediterranean area, where important funds are dedicated to fire prevention and suppression, the spatial pattern of fire likelihood remains extremely uneven (Fig. 5) due to the spatial interactions between top-down (climate) and bottom-up (fuel, ignition patterns) factors. While the projected extent of WUI and vegetation shifts due to climate change has been identified as one of the critical factors that will determine future shifts in wildfire hazard (Moreira et al. 2011; Batllori et al. 2013; Liu and Wimberley 2016), our results also suggest that local changes in fire weather should be taken into account when projecting

\section{Acknowledgments}

454 This work is a contribution to the UE 7th FP Env.1.3.1.1 FUME "Forest fires under 455 climate, social and economic changes in Europe, the Mediterranean and other fire456 affected areas of the world,' Grant agreement no. 243888. A doctoral research Grant 457 to J. Ruffault was provided by the Languedoc-Roussillon (LR) region and the Centre 458 National de la Recherche Scientifique (CNRS). This work is also a contribution to the 459 Labex OT-Med (ANR-11-LABEX-0061) funded by the "Investissements d'Avenir," 460 French Government program of the French National Research Agency (ANR) through 461 the A*Midex project (ANR-11-IDEX-0001-02). We thank the associate editor and two 462 anonymous reviewers for their constructive comments, which helped us improve our 463 paper. 


\section{References}

465

466

Archibald S, Roy DP, Van Wilgen BW, Scholes RJ (2009) What limits fire? An examination of drivers of burnt area in Southern Africa. Global Change Biology 15, 613-630. doi:10.1111/j.13652486.2008.01754.x.

Batllori E, Parisien MA, Krawchuk MA, Moritz MA (2013) Climate change-induced shifts in fire for Mediterranean ecosystems. Global Ecology and Biogeography 22, 1118-1129. doi:10.1111/geb.12065.

Bar-Massada A, Syphard AD, Stewart SI, Radeloff VC (2013) Wildfire ignition-distribution modelling: a comparative study in the Huron-Manistee National Forest, Michigan, USA. International Journal of Wildland Fire 22, 174-183. doi: 10.1071/WF11178

Boer MM, Bowman DMJS, Murphy BP, Cary GJ, Cochrane MA, Fensham RJ, Krawchuk MA, Price OF, Resco De Dios V, Williams RJ, Bradstock RA (2016) Future changes in climatic water balance determine potential for transformational shifts in Australian fire regimes. Environmental Research Letters 11, 65002. doi:10.1088/1748-9326/11/6/065002.

Bowman DMJS, Balch J, Artaxo P, Bond WJ, Cochrane MA, D'Antonio CM, Defries R, Johnston FH, Keeley JE, Krawchuk MA, Kull CA, Mack M, Moritz MA, Pyne S, Roos CI, Scott AC, Sodhi NS, Swetnam TW (2011) The human dimension of fire regimes on Earth. Journal of Biogeography 38, 2223-2236. doi:10.1111/j.1365-2699.2011.02595.x.

Bradstock RA (2010) A biogeographic model of fire regimes in Australia: Current and future implications. Global Ecology and Biogeography 19, 145-158. doi:10.1111/j.14668238.2009.00512.x.

Brotons L, Aquilué N, de Cáceres M, Fortin MJ, Fall A (2013) How Fire History, Fire Suppression Practices and Climate Change Affect Wildfire Regimes in Mediterranean Landscapes. PLoS ONE 8, e62392. doi:10.1371/journal.pone.0062392.

Cardille JA, Ventura SJ (2001) Environmental and Social Factors Influencing Wildfires in the Upper Midwest, United States. Ecological Applications 11, 111-127. doi:10.1890/10510761(2001)011[0111:EASFIW]2.0.CO;2.

Cary GJ, Keane RE, Gardner RH, Lavorel S, Flannigan MD, Davies ID, Li C, Lenihan JM, Rupp TS, Mouillot F (2006) Comparison of the sensitivity of landscape-fire-succession models to variation in terrain, fuel pattern, climate and weather. Landscape Ecology 21, 121-137. doi:10.1007/s10980005-7302-9.

Curt T, Fréjaville T, Lahaye S (2016) Modelling the spatial patterns of ignition causes and fire regime features in southern France: Implications for fire prevention policy. International Journal of Wildland Fire 25, 785-796. doi:10.1071/WF15205.

De'ath G (2007) Boosted trees for ecological modeling and prediction. Ecology 88, 243-251. doi:10.1890/0012-9658(2007)88[243:BTFEMA]2.0.CO;2.

Duane A, Piqué M, Castellnou M, Brotons L (2015) Predictive modelling of fire occurrences from different fire spread patterns in Mediterranean landscapes. International Journal of Wildland Fire 24, 407-418. doi:10.1071/WF14040.

EEA (1994) Corine Land Cover report. (European Environmental Agency) Available at http://www.eea.europa.eu/publications/COR0-landcover

Elith J, Leathwick JR, Hastie TJ (2008) A working guide to boosted regression trees. Journal of Animal Ecology 77, 802-813. doi:10.1111/j.1365-2656.2008.01390.x.

Faivre N, Jin Y, Goulden ML, Randerson JT (2014) Controls on the spatial pattern of wildfire ignitions in Southern California. International Journal of Wildland Fire 23, 799-811. doi:10.1071/WF13136.

Fernandes PM, Monteiro-Henriques T, Guiomar N, Loureiro C, Barros AMG (2016) Bottom-Up Variables Govern Large-Fire Size in Portugal. Ecosystems 19, 1362-1375. doi:10.1007/s10021016-0010-2. 
Fréjaville T, Curt T (2015) Spatiotemporal patterns of changes in fire regime and climate: defining the pyroclimates of south-eastern France (Mediterranean Basin). Climatic Change 129, 239-251. doi:10.1007/s10584-015-1332-3.

Gaultier JP, Legros JP, Bornand M, King D, Favrot JC, Hardy R (1993) L'organisation et la gestion des données pédologiques spatialisées: Le projet DONESOL. Revue de Géomatique 3, 235-253.

Hantson S, Pueyo S, Chuvieco E (2015) Global fire size distribution is driven by human impact and climate. Global Ecology and Biogeography 24, 77-86. doi:10.1111/geb.12246.

Hargrove W W, Gardner R H, Turner M G, Romme WH, Despain DG (2000) Simulating fire patterns in heterogeneous landscapes. Ecological Modelling 135, 243-263. doi:10.1016/S03043800(00)00368-9.

Hawbaker TJ, Radeloff VC, Stewart SI, Hammer RB, Keuler NS, Clayton MK (2013) Human and biophysical influences on fire occurrence in the United States. Ecological Applications 23, 565582. doi:10.1890/12-1816.1.

Heyerdahl EK, Brubaker LB, Agee JK (2001) Spatial controls of historical fire regimes: A multiscale example from the interior west, USA. Ecology 82, 660-678. doi:10.1890/00129658(2001)082[0660:SCOHFR]2.0.CO;2.

Higuera PE, Abatzoglou JT, Littell JS, Morgan P (2015) The changing strength and nature of fire-climate relationships in the northern Rocky Mountains, U.S.A., 1902-2008. PLoS ONE 10, e0127563. doi:10.1371/journal.pone.0127563.

IGN (2007) BD Topo 2000, Institut Géographique National. Available at http://professionnels.ign.fr/bdtopo

Jolly WM, Cochrane MA, Freeborn PH, Holden ZA, Brown TJ, Williamson GJ, Bowman DMJS (2015) Climate-induced variations in global wildfire danger from 1979 to 2013. Nature Communications 6, 7537. doi:10.1038/ncomms8537.

Krawchuk MA, Moritz MA, Parisien M-A, Van Dorn J, Hayhoe K (2009) Global pyrogeography: The current and future distribution of wildfire. PLOS ONE 4, e5102. doi:10.1371/journal.pone.0005102.

Lampin-Maillet C, Jappiot M, Long M, Bouillon C, Morge D, Ferrier JP (2010) Mapping wildland-urban interfaces at large scales integrating housing density and vegetation aggregation for fire prevention in the South of France. Journal of Environmental Management 91, 732-741. doi:10.1016/j.jenvman.2009.10.001.

Lionello P, Malanotte-Rizzoli P, Boscolo R, Alpert P, Artale V, Li L, Luterbacher J, May W, Trigo R, Tsimplis M, Ulbrich U, Xoplaki E (2006) The Mediterranean climate: An overview of the main characteristics and issues. Developments in Earth and Environmental Sciences 4, 1-26. doi:10.1016/S1571-9197(06)80003-0.

Liu Z, Wimberly MC (2016) Direct and indirect effects of climate change on projected future fire regimes in the western United States. Science of the Total Environment 542, 65-75. doi:10.1016/j.scitotenv.2015.10.093.

Liu Z, Yang J, He HS (2013) Identifying the threshold of dominant controls on fire spread in a boreal forest landscape of Northeast China. PloS ONE 8, e55618. doi:10.1371/journal.pone.0055618.

Lobo JM, Jiménez-Valverde A, Real R (2008) AUC: A misleading measure of the performance of predictive distribution models. Global Ecology and Biogeography 17, 145-151. doi:10.1111/j.1466-8238.2007.00358.x.

Loepfe L, Martinez-Vilalta J, Oliveres J, Piñol J, Lloret F (2010) Feedbacks between fuel reduction and landscape homogenisation determine fire regimes in three Mediterranean areas. Forest Ecology and Management 259, 2366-2374. doi:10.1016/j.foreco.2010.03.009.

López-Moreno JI, Goyette S, Beniston M (2008) Climate change prediction over complex areas: Spatial variability of uncertainties and predictions over the Pyrenees from a set of regional climate models. International Journal of Climatology 28, 1535-1550. doi:10.1002/joc.1645.

Mann ML, Batllori E, Moritz MA, Waller EK, Berck P, Flint AL, Flint LE, Dolfi E (2016) Incorporating Anthropogenic Influences into Fire Probability Models: Effects of Human Activity and Climate Change on Fire Activity in California. PLOS ONE 11, 1-21. doi:10.1371/journal.pone.0153589. 
Marlon JR, Bartlein PJ, Carcaillet C, Gavin DG, Harrison SP, Higuera PE, Joos F, Power MJ, Prentice IC (2008) Climate and human influences on global biomass burning over the past two millennia. Nature Geoscience 1, 697-702. doi:10.1038/ngeo468.

Martínez J, Vega-Garcia C, Chuvieco E (2009) Human-caused wildfire risk rating for prevention planning in Spain. Journal of Environmental Management 90, 1241-1252. doi:10.1016/j.jenvman.2008.07.005.

McGarigal K, Cushman SA, Neel MC, Ene E (2002) FRAGSTATS: Spatial Pattern Analysis Program for Categorical Maps. Analysis 3.3, The following citation is recommended by the autho. doi:Cited By (since 1996) 586 rrExport Date 3 May 2012.

Moreira F, Catry FX, Rego F, Bacao F (2010) Size-dependent pattern of wildfire ignitions in Portugal: When do ignitions turn into big fires? Landscape Ecology 25, 1405-1417. doi:10.1007/s10980010-9491-0.

Moreira F, Viedma O, Arianoutsou M, Curt T, Koutsias N, Rigolot E, Barbati A, Corona P, Vaz P, Xanthopoulos G, Mouillot F, Bilgili E (2011) Landscape--wildfire interactions in southern Europe: implications for landscape management. Journal of Environmental Management 92, 2389-402. doi:10.1016/j.jenvman.2011.06.028.

Moritz MA, Morais ME, Summerell LA, Carlson JM, Doyle J (2005) Wildfires, complexity, and highly optimized tolerance. Proceedings of the National Academy of Sciences of the United States of America 102, 17912-7. doi:10.1073/pnas.0508985102.

Moritz MA, Moody TJ, Krawchuk MA, Hughes M, Hall A (2010) Spatial variation in extreme winds predicts large wildfire locations in chaparral ecosystems. Geophysical Research Letters 37, L04801-L04801. doi:10.1029/2009GL041735.

Mouillot F, Ratte JP, Joffre R, Moreno JM, Rambal S (2003) Some determinants of the spatio-temporal fire cycle in a mediterranean landscape (Corsica, France). Landscape Ecology 18, 665-674. doi:10.1023/B:LAND.0000004182.22525.a9.

Olden JD, Lawler JJ, Poff NL (2008) Machine learning methods without tears: a primer for ecologists. The Quarterly Review of Biology 83, 171-193. doi:10.1086/587826.

Oliveira S, Oehler F, San-miguel-ayanz J, Camia A, Pereira JMC (2012) Forest Ecology and Management Modeling spatial patterns of fire occurrence in Mediterranean Europe using Multiple Regression and Random Forest. Forest Ecology and Management 275, 117-129. doi:10.1016/j.foreco.2012.03.003.

Parisien MA, Parks SA, Krawchuk MA, Flannigan MD, Bowman LM, Moritz MA (2011b) Scaledependent controls on the area burned in the boreal forest of Canada, 1980-2005. Ecological Applications 21, 789-805. doi:10.1890/10-0326.1.

Parisien MA, Parks SA, Miller C, Krawchuk MA, Heathcott M, Moritz MA (2011a) Contributions of Ignitions, Fuels, and Weather to the Spatial Patterns of Burn Probability of a Boreal Landscape. Ecosystems 14, 1141-1155. doi:10.1007/s10021-011-9474-2.

Parisien MA, Parks SA, Krawchuk MA, Little JM, Flannigan MD, Gowman LM, Moritz MA (2014) An analysis of controls on fire activity in boreal Canada: Comparing models built with different temporal resolutions. Ecological Applications 24, 1341-1356. doi:10.1890/13-1477.1.

Parisien MA, Moritz MA (2009) Environmental controls on the distribution of wildfire at multiple spatial scales. Ecological Monographs 79, 127-154. doi:10.1890/07-1289.1.

Parisien MA, Miller C, Parks SA, DeLancey ER, Robinne F-N, Flannigan MD (2016) The spatially varying influence of humans on fire probability in North America. Environmental Research Letters 11, 75005. doi:10.1088/1748-9326/11/7/075005.

Parisien MA, Snetsinger S, Greenberg JA, Nelson CR, Schoennagel T, Dobrowski SZ, Moritz MA (2012) Spatial variability in wildfire probability across the western United States. International Journal of Wildland Fire 21, 313-327. doi:10.1071/WF11044.

Parks SA, Parisien MA, Miller C (2012) Spatial bottom-up controls on fire likelihood vary across western North America. Ecosphere 3(1), 20. doi:10.1890/ES11-00298.1. 
614

615

616

617

618

619

620

621

622

623

624

625

626

627

628

629

630

631

632

633

634

635

636

637

638

639

640

641

642

643

644

645

646

647

648

649

650

651

652

653

654

655

656

657

658

Pausas JG, Paula S (2012) Fuel shapes the fire-climate relationship: Evidence from Mediterranean ecosystems. Global Ecology and Biogeography 21, 1074-1082. doi:10.1111/j.14668238.2012.00769.x.

Piñol J, Terradas J, Lloret F (1998) Climate warming, wildfire hazard, and wilfire occurence in coastal eastern Spain. International Journal of Wildland fire 11, 95-106. doi:10.1023/A:1005316632105.

Ridgeway G (2006) Generalized boosted regression models. Documentation on the R Package 'gbm', version 1,7 .

Robinne FN, Parisien M-A, Flannigan M (2016) Anthropogenic influence on wildfire activity in Alberta, Canada. International Journal of Wildland Fire 25, 1131-1143. doi:10.1071/WF16058.

Rothermel RC (1991) Predicting behavior and size of crown fires in the northern Rocky Mountains. USDA Forest Service, Intermountain Research Station, Research Paper 46.

Ruffault J, Moron V, Trigo RM, Curt T (2017) Daily synoptic conditions associated with large fire occurrence in Mediterranean France: evidence for a wind- driven fire regime. International Journal of Climatology 37, 524-533. doi:10.1002/joc.4680.

Ruffault J, Moron V, Trigo RM, Curt T (2016) Objective identification of multiple large fire climatologies: an application to a Mediterranean ecosystem. Environmental Research Letters 11, 75006. doi:10.1088/1748-9326/11/7/075006.

Ruffault J, Mouillot F (2015) How a new fire-suppression policy can abruptly reshape the fire-weather relationship. Ecosphere 6, 1-19. doi:10.1890/ES15-00182.1.

Ruffault J, Martin-StPaul NK, Rambal S, Mouillot F (2013) Differential regional responses in drought length, intensity and timing to recent climate changes in a Mediterranean forested ecosystem. Climatic Change 117, 103-117. doi:10.1007/s10584-012-0559-5.

Ruffault J, Martin-StPaul N, Duffet C, Goge F, Mouillot F (2014) Projecting future drought in Mediterranean forests: bias correction of climate models matters! Theoretical and Applied Climatology 117, 113-122. doi:10.1007/s00704-013-0992-z.

Syphard AD, Radeloff VC, Keeley JE, Hawbaker TJ, Clayton MK, Stewart SI, Hammer RB (2007) Human influence on California fire regimes. Ecological Applications 17, 1388-1402. doi:10.1890/06-1128.1.

Syphard AD, Radeloff VC, Keuler NS, Taylor RS, Hawbaker TJ, Stewart SI, Clayton MK (2008) Predicting spatial patterns of fire on a southern California landscape. International Journal of Wildland Fire 17, 602. doi:10.1071/WF07087.

Vidal JP, Martin E, Franchistéguy L, Baillon M, Soubeyroux JM (2010) A 50-year high-resolution atmospheric reanalysis over France with the Safran system. International Journal of Climatology 30, 1627-1644. doi:10.1002/joc.2003.

Viedma O, Angeler DG, Moreno JM (2009) Landscape structural features control fire size in a Mediterranean forested area of central Spain. International Journal of Wildland Fire 18, 575-583. doi:10.1071/WF08030.

Whitman E, Batllori E, Parisien MA, Miller C, Coop JD, Krawchuk MA, Chong GW, Haire SL (2015) The climate space of fire regimes in north-western North America. Journal of Biogeography 42 , 1736-1749. doi:10.1111/jbi.12533.

Williams AP, Seager R, MacAlady AK, Berkelhammer M, Crimmins MA, Swetnam TW, Trugman AT, Buenning N, Noone D, McDowell NG, Hryniw N, Mora CI, Rahn T (2015) Correlations between components of the water balance and burned area reveal new insights for predicting forest fire area in the southwest United States. International Journal of Wildland Fire 24, 14-26. doi:10.1071/WF14023. 
659 Table 1. Selected explanatory variables used as inputs in boosted regression tree (BRT)

660 models for predicting the spatial distribution of fires in Mediterranean France. Maps of

661 the fire weather season length (FWSL) are shown in Fig. 2. Maps of the human and 662 fuel-related variables are shown in Fig. S1. Human and land cover variables were 663 derived from the BD Topo (IGN 2007) and Corine land cover (EEA 1994) databases, 664 respectively.

665

\begin{tabular}{lll}
\hline Variable & Unit & Data source \\
\hline Humans & & \\
Road density & $\mathrm{km}_{\mathrm{km}} \mathrm{km}^{-2}$ & BD Topo \\
Housing density & $\mathrm{nb} \cdot \mathrm{km}^{-2}$ & BD Topo \\
Wildland Urban interface (WUI) & $\mathrm{km}^{2} \cdot \mathrm{km}^{-2}$ & BD Topo \\
Fuel/Land cover & & \\
Shrubland area & $\%$ & Corine land cover \\
Forest area & $\%$ & Corine land cover \\
Landscape diversity & - & Corine land cover \\
Weather & & \\
Fire weather season length (FWSL) & days & \\
\hline
\end{tabular}


666 Table 2. Performance of spatial boosted regression tree (BRT) models in predicting the 667 spatial distribution of fires in southern France between 1990 and 2006 and for different 668 final fire size classes. For each model, $70 \%$ of the grid cells were used to build models 669 and the remaining 30\% were used for validation. Means and standard deviations of an 670 ensemble of $25 B R T$ models are given. AUC is the area under the receiving operator 671 curve (ROC) curve. The commission error (false positives) is the percentage of fire 672 events misclassified as absences. The omission error is the percentage of non-fire events 673 misclassified as presences (false negatives). The probability threshold is minimized 674 according to the sum of these two values.

\begin{tabular}{llll}
\hline Fire size & $\begin{array}{l}\text { Omission } \\
\text { error (\%) }\end{array}$ & $\begin{array}{l}\text { Commission } \\
\text { error (\%) }\end{array}$ & AUC \\
\hline$>0$ ha & $34.0 .(3.5)$ & $31.0(2.8)$ & $0.73(1.2)$ \\
$>1$ ha & $33.8(3.6)$ & $32.6(3.7)$ & $0.72(1.6)$ \\
$>6$ ha & $34.7(3.3)$ & $31.9(5.3)$ & $0.72(2.7)$ \\
$>15$ ha & $35.0(5.4)$ & $32.7(6.4)$ & $0.72(3.6)$ \\
$>30$ ha & $34.7(8.3)$ & $32.0(8.9)$ & $0.72(4.3)$ \\
\hline
\end{tabular}


676 Table 3. Correlation among the mean contributions of each variable to boosted

677 regression tree (BRT) models predicting the spatial distribution of fires for different 678 final fire size classes. Spearman correlation coefficient $(\rho)$ and its associated P-value 679 are reported $(* \mathrm{P}<0.1 ; * * \mathrm{P}<0.01)$.

680

\begin{tabular}{llllll}
\hline Fire size & $>\mathbf{0}$ ha & $>\mathbf{1}$ ha & $\mathbf{> 6}$ ha & $>\mathbf{1 5}$ ha & $>\mathbf{3 0}$ ha \\
\hline$>\mathbf{0}$ ha & 1 & & & & \\
$>\mathbf{1}$ ha & $0.92^{* *}$ & 1 & & & \\
$>\mathbf{6}$ ha & 0.17 & 0.50 & 1 & & \\
$>\mathbf{1 5}$ ha & 0.14 & 0.46 & 0.75 & 1 & \\
$>\mathbf{3 0}$ ha & 0.32 & 0.59 & $0.89^{*}$ & $0.89^{*}$ & 1 \\
\hline
\end{tabular}



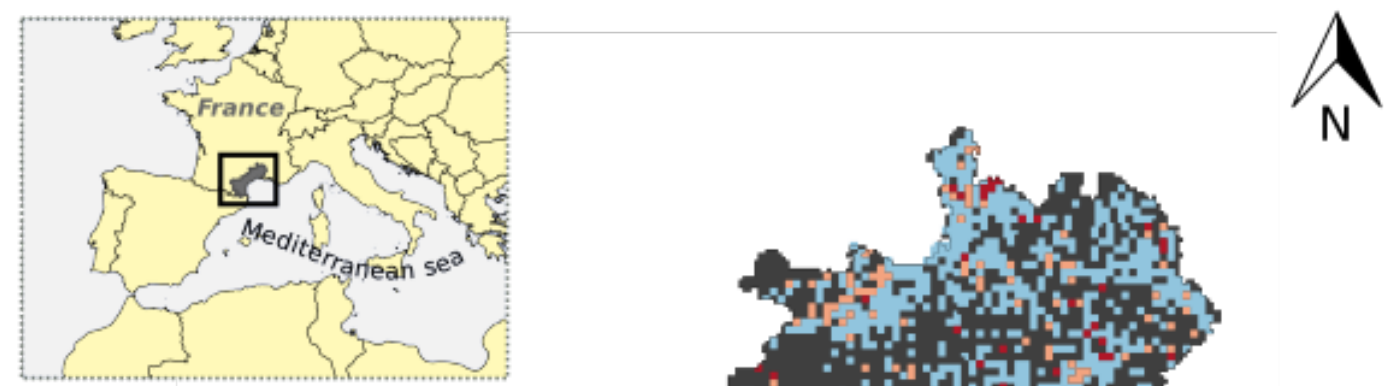

683

684 Figure 1: Map of the study area showing the spatial distribution of fires as a function

685 of the maximum fire size observed in each grid cell between 1990 and 2006. 
Figure 2

a) Fire weather season length for all fires
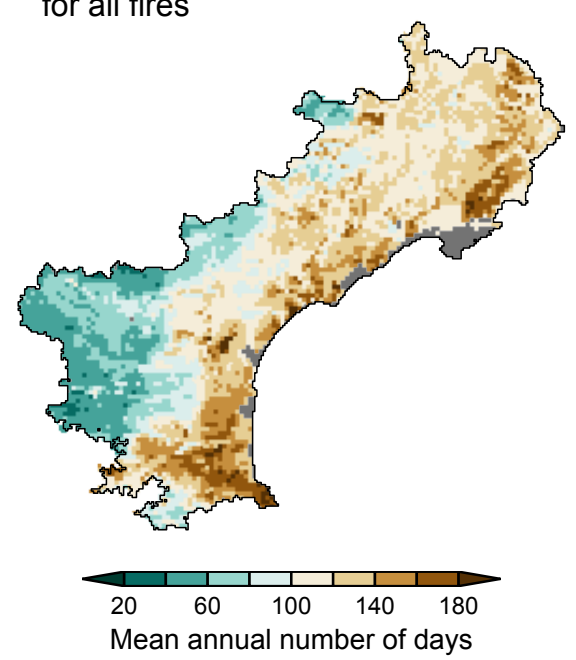

b) Fire weather season length for large fires

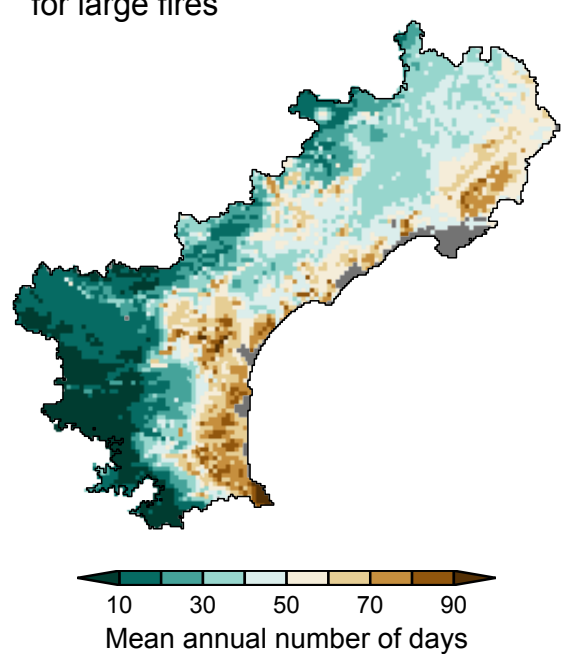

688 Figure 2. Mean annual fire weather season length (FWSL) between 1990 and 2006 for

689 a) all fires and b) large fires (30 ha). Note the different scales between the two panels. 

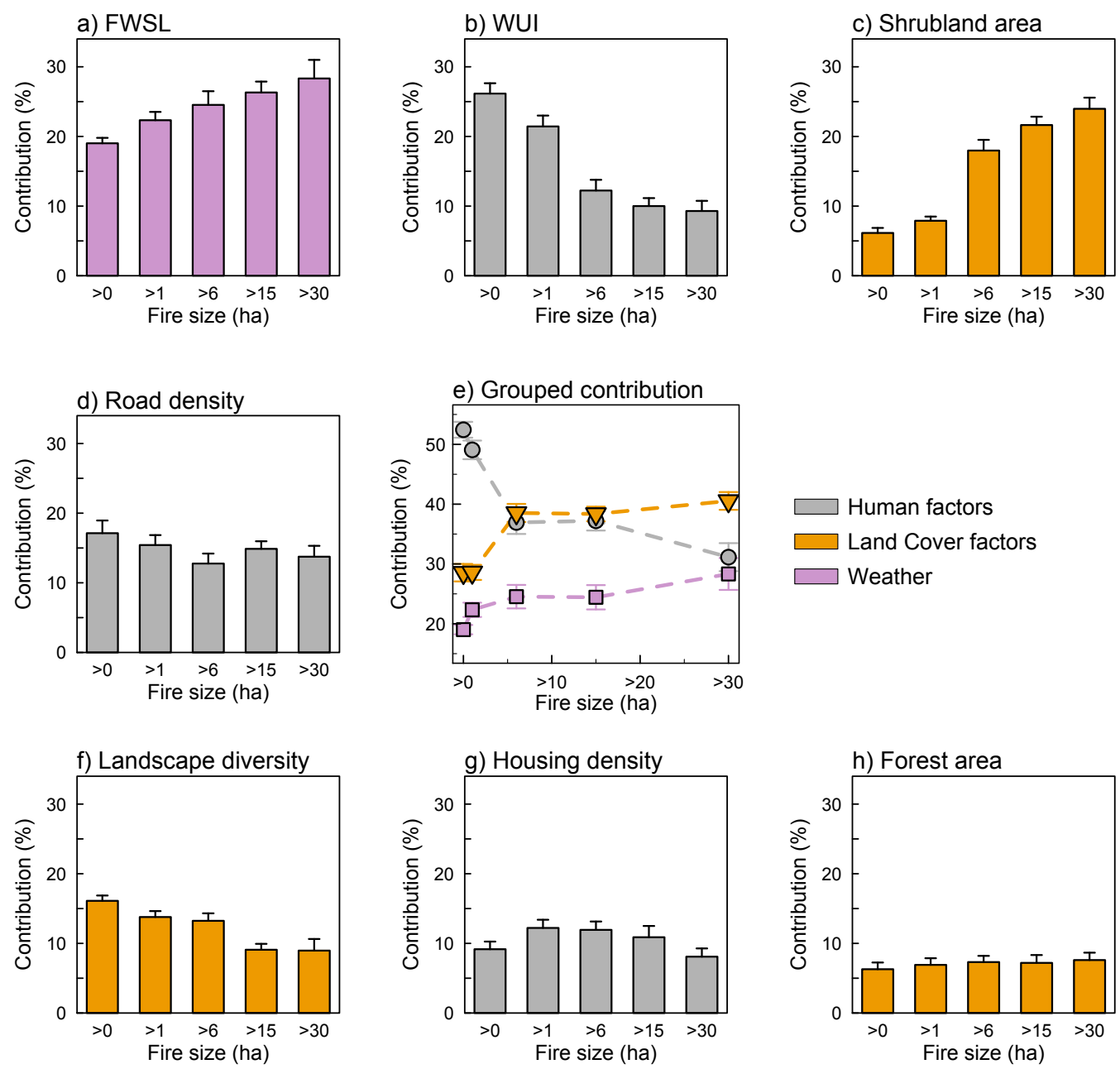

692 Figure 3. Relative contribution of explanatory variables in the boosted regression tree

693 (BRT) models predicting the spatial distribution of fires for different final fire size

694 classes between 1990 and 2006. The contributions of individual (a-d, f-h) and grouped 695 variables (e) are given. For each fire size, the mean and the standard deviation of an 696 ensemble of 25 models are represented. FWSL is the fire weather season length. WUI 697 is the wildland urban interface. 

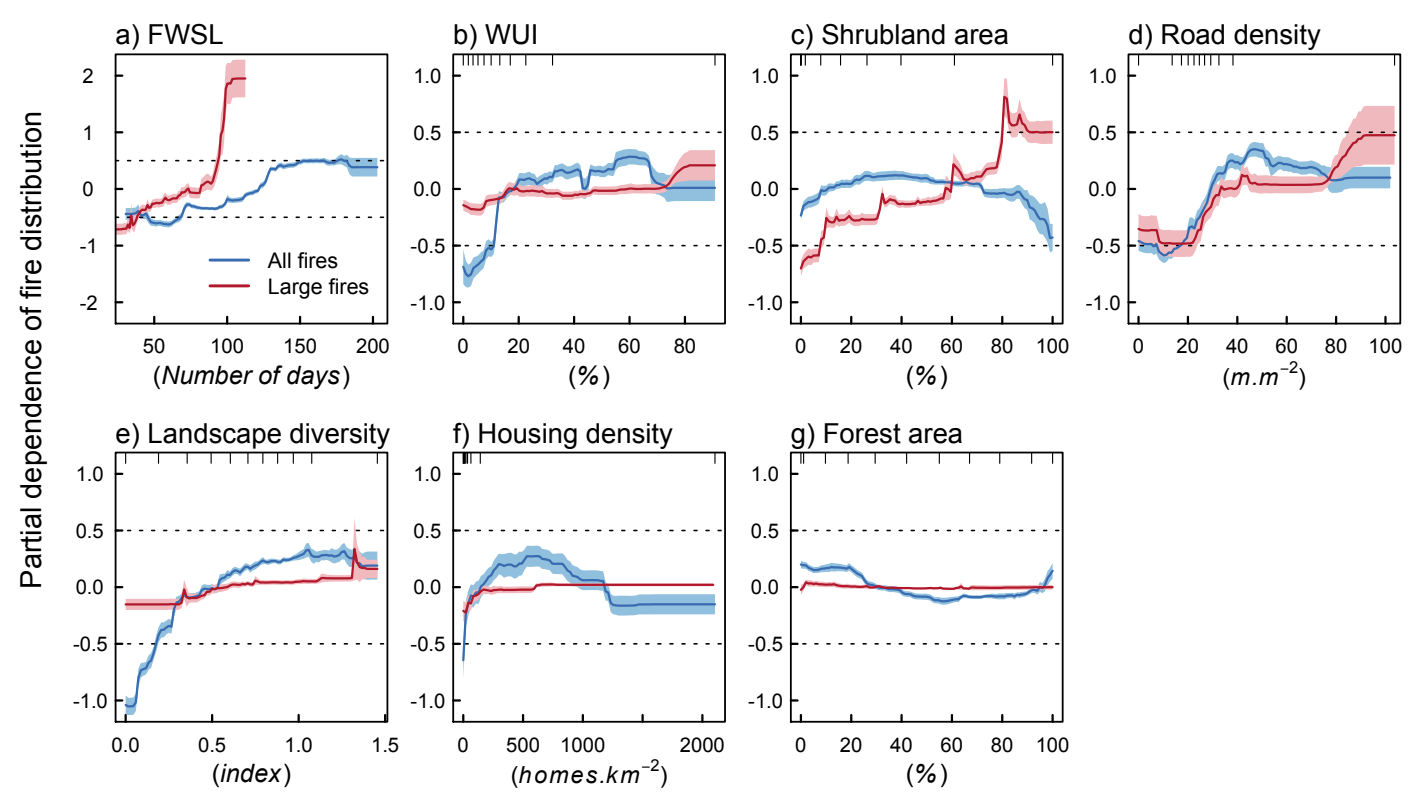

699

700 Figure 4. Partial dependence of spatial distribution of all fires and large fires ( $>30 \mathrm{ha})$

701 on the 7 explanatory variables. Partial dependence expresses the expected response in

702 the spatial distribution of fires for a variable of interest when all other variables are held

703 constant. The mean and the confidence interval of an ensemble of 25 models are given.

704 FWSL is the fire weather season length and WUI is the wildland-urban interface. 
Figure 5
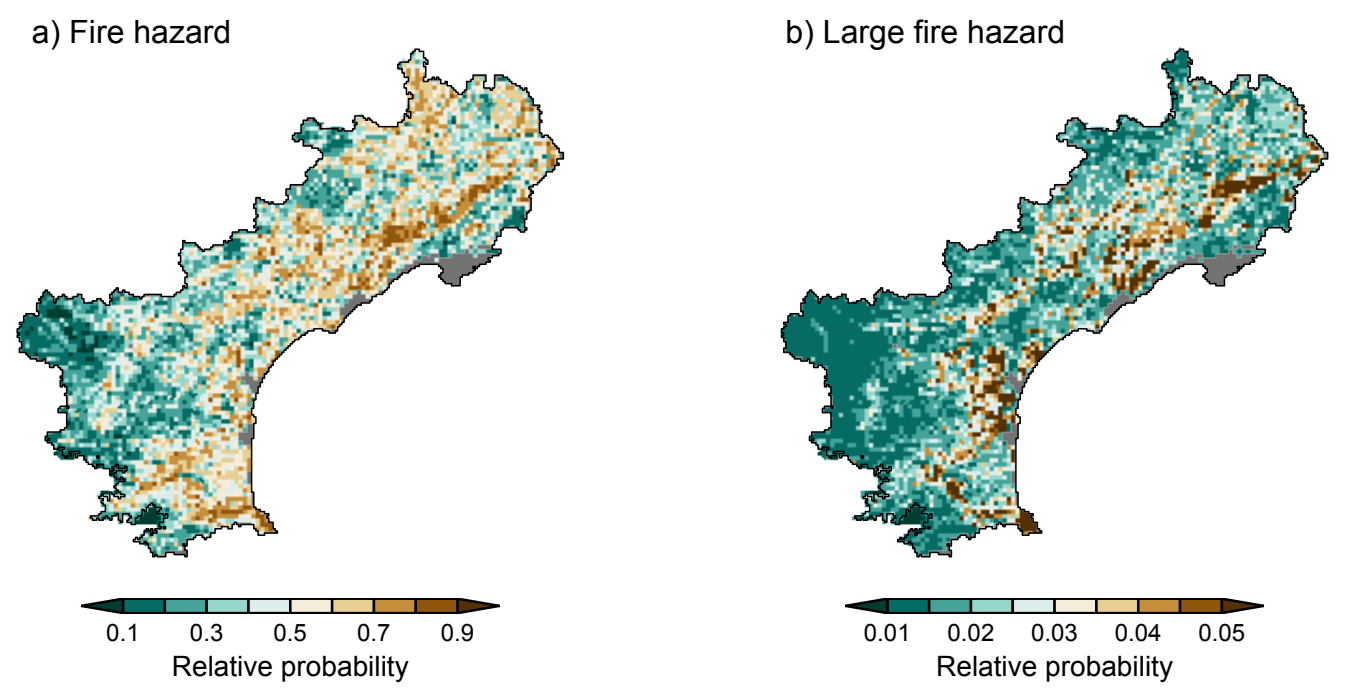

706

Figure 5. Fire hazard for a) all fires and b) large fires ( $>30$ ha) determined with boosted 708 regression tree (BRT) models from 7 key explanatory variables related to humans, 709 weather and land cover characteristics of the landscape between 1990 and 2006. Note 710 the different scales between the two panels. 